\title{
BRACHYTHECIUM BUCHANANII (BRACHYTHECIACEAE, MUSCI) - A NEW SPECIES FOR UZBEKISTAN
}

\section{BRACHYTHECIUM BUCHANANII (BRACHYTHECIACEAE, MUSCI) - НОВЫЙ ВИД ДЛЯ ФЛОРЫ УЗБЕКИСТАНА}

\author{
M. S. IGNATOV ${ }^{1} \&$ E. A. IGNATOVA ${ }^{2}$ \\ М. С. ИГнатов ${ }^{1} \&$ Е. А. ИГНАТовА ${ }^{2}$
}

Abstract

\begin{abstract}
Brachythecium buchananii (Hook.) A. Jaeg. is found in Uzbekistan for the first time. This species is widespread in China, Corea, Japan, and Himalayas, and was also known from South Siberia, Russian Far East, and from Pakistan. The differential characters of B. buchananii are discussed and illustrated.
\end{abstract}

Резюме

Brachythecium buchananii (Hook.) A. Jaeg. впервые выявлен для Узбекистана. Ранее этот широко распространенный в Китае, Корее, Японии и Гималаях вид был известен для Южной Сибири и Российского Дальнего Востока; кроме того этот вид известен из Пакистана. Обсуждаются и иллюстрируются диагостические признаки B. buchananii.

Identifying old collections from various areas of the Middle Asia stored in MW, we found a small, ca. 40 specimens, collection of L. Nazarenko from Uzbekistan. One species from it appeared to be Brachythecium buchananii, a species new for Uzbekistan as well as the whole area of the Middle Asia (cf. Mamatkulov \& al., 1998).

The label is as follow: Gorno-archevyj [=Mountain Juni perus] Reserve "Guralash", \{Kuyan-Saj? - ambigous handwriting\}, Wfaced slope, in arborescent Juniperus stand, coll. L. Nazarenko \#122, 24.V.1947 (MW).

The locality is on the Northern macroslope of TurkestanskyRidge, ca. $39^{\circ} 40^{\prime} \mathrm{N}-68^{\circ} 15-20^{\prime} \mathrm{E}$.

Brachythecium buchananii is a species widespread in China, Corea, Japan, and Himalayas, and it was found also in South Siberia (Ignatov, 1998); Russian Far East (Ignatov \& al., 2000), and one very isolated locality is in Central Yakutiya (Krivoshapkin \& al., 2001). Westwards it ranges to Pakistan (Nishimura \& Higuchi, 1993). In the Middle Asia B. buchananii was never recorded, apparently because its presence in the area simply was not expected. It is quite likely, that an expanded search in Tadjikstan allow to discover it there too.
Brachythecium buchananii more commonly resembles a small expression of $B$. glareosum, with very concave basal part, which has very lax areolation. However the variability of this species is enormous, resulting in that it was described many times under different names (cf. Ignatov \& Koponen, 1996). Plants from more xeric environments, including that from Uzbekistan, often have less concave base, and the basal quadrate or subquadrate cells sometimes are quite numerous, reaching more than half distance to the costa. These undeveloped plants might be difficult to distinquish from the so unrelated species as Sciurohypnum (Brachythecium) plumosum (Hedw.) Ignatov et Huttunen. The latter species is rather homogeneous in boreal regions of the northern Hemisphere, but in East Asia it often grows in rather dry places, producing very slender plants with long-acuminate leaevs and relatively long cells. The reliable character which might help in the case when the leaf features are not suggestive is the shape of pseudoparaphyllia (called as juvenille leaves by some authors): in Sciurohypnum they are acute and triangular in shape, whereas in B. buchananii they are acuminate - more shortly around dormant initialls (cf. Fig. 1-6), or more longly in uppermost part of

1 - Main Botanical garden of Russian Acad. Sci., Botanicheskaya 4, Moscow 127276 Russia - Россия 127276 Москва, Ботаническая 4, Главный ботанический сад РАН

2 - Moscow State University, Biological Faculty, Moscow 119992 Russia - Россия 119992 Москва, Московский государственный университ, Биологический факультет 


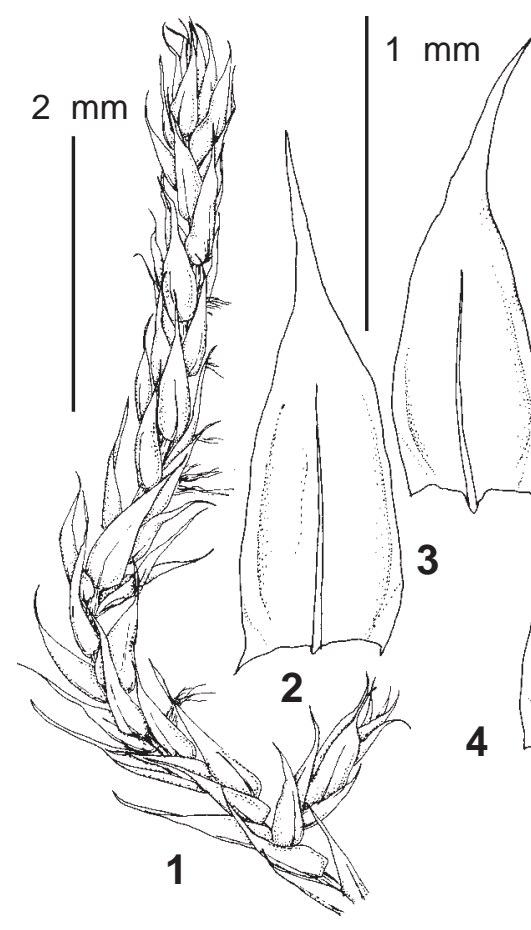

Fig. 1. Brachythecium buchananii (Hook.) A. Jaeg. (Uzbekistan, Nazarenko 24.V.1947, MW): 1 - habit; 2-4 - leaves; 5 - axillary hair; 6 - branch initial; 7 - upper laminal cells; 8 - midleaf cells; 9 basal cells. Scale bars: $2 \mathrm{~mm}$ for $1 ; 1 \mathrm{~mm}-2-4 ; 0.5$ $\mathrm{mm}-6 ; 100 \mu \mathrm{m}-5,7-9$.
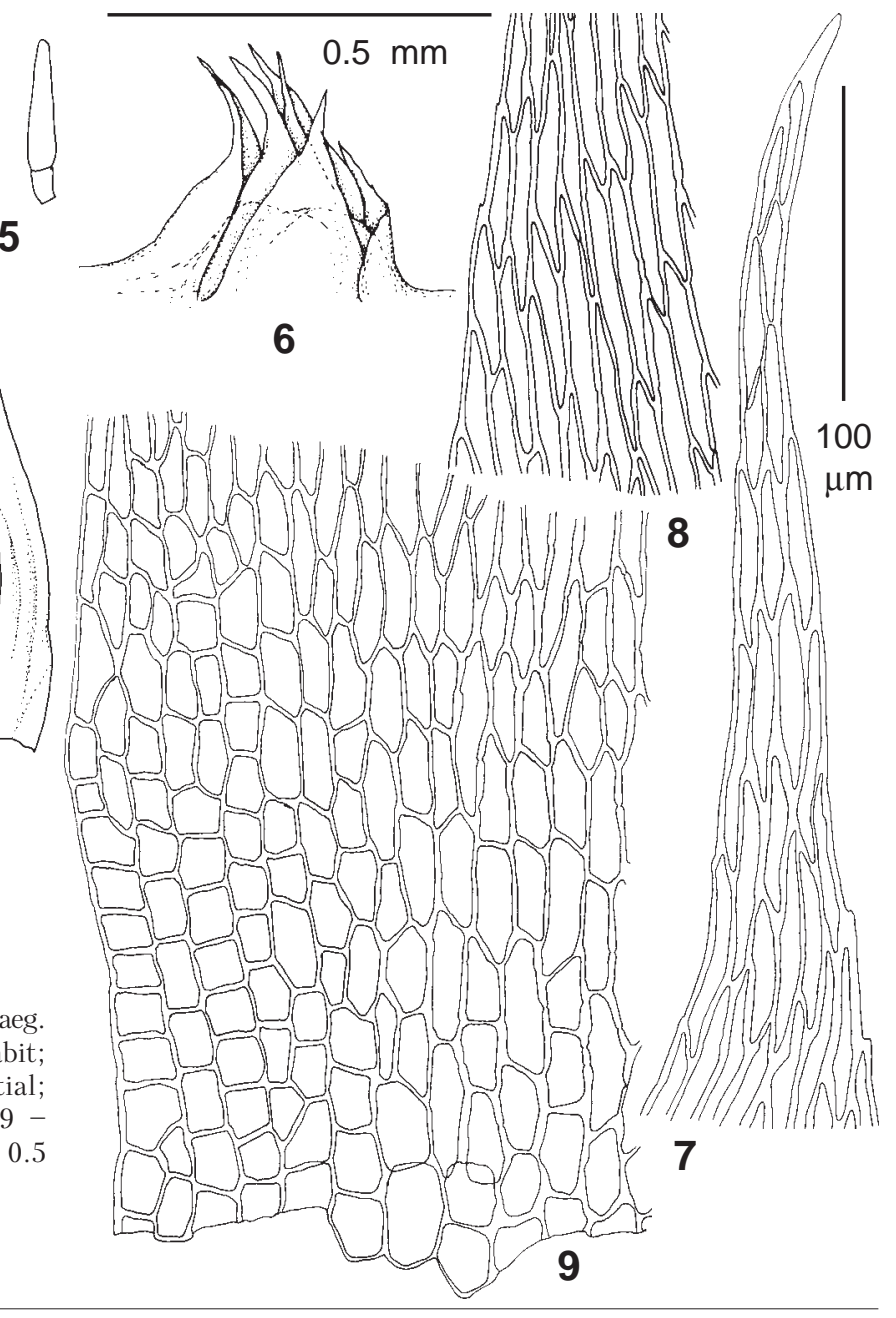

stem. Another characteristic of B. buchananii is (3)2-celled axillary hairs with upper cell gradually tapered to its distal end vs. (2-)3-celled hair in Sciurohypnum plumosum with more or less blunly ended upper cell. Brachythecium buchananii differs from other species of Brachythecium primarily by its small size, and from species of B. salebrosum s. 1. also by the subentire (not serrulate, especially in upper leaf) leaf margin.

\section{ACKNOWLEDGEMENTS}

The work was partly supported by the programm "Biodiversity" of the Russian Academy of Sciences.

\section{LITERATURE CITED}

IGNATOV, M. S. 1998. Bryophyte flora of Altai Mountains. VIII. Brachytheciaceae. - Arctoa 7: 85-152.

[KRIVOSHAPKIN, K. K., M. S. IGNATOV \& E. A. IGNATOVA] КРИВОШАПКИН, К. К., М. С. ИГНАТОВ, Е. А.ИГНАТОВА 2001. К флоре листостебельных мхов Национального природного парка “Ленские столбы” (устье р. Лабыйа). - [On moss flora of National Nature Park "Lenskie Stolby" (Labyja Creek mouth)] B кн.: Национальный природный парк “Ленские Столбъз" : геология, почвы, растительность, животный мир, охрана и использование. Якутск, НПП "Ленские Стлобь" [In: Nationalnyj Prirodny Park "Lenskie Stolby” : geologiya, pochoy, rastitelnost, zhivotny mir, ochrana i ispolzovanie. Yakutsk, NPP “Lenskie Stolby” \& al.]: 71-81.
IGNATOV, M. S. \& T. KOPONEN 1996. On the taxonomy of some East Asian Brachythecium (Brachytheciaceae, Musci). - Ann. Bot. Fennici 33: 285-301.

IGNATOV, M. S., B. C. TAN, Z. IWATSUKI \& E. A. IGNATOVA 2000. Moss flora of the Upper Bureya River (Russian Far East). - J. Hattori Bot. Lab. 88: 147-178.

[MAMATKULOV, U. K., I. O. BAITULIN \& S. G. NESTEROVA] МАMАТКУЛОВ, У. К., И. О. БАЙТУЛИН, С. Г. НЕСТЕРОВА 1998. Мохообразные Средней Азии и Казахстана. - [Bryophytes of the Middle Asia and Kazakhstan] Aлматы [Almaty], 232.

NISHIMURA, N. \& M. HIGUCHI 1993. Checklist of mosses of Pakistan. - Cryptogamic Flora of Pakistan 2: 275-299. 